\title{
THE LEVERAGE EFFECT ON STOCK RETURNS
}

\author{
Roberta Adami ${ }^{\mathrm{a}^{*}}$ \\ Orla Gough ${ }^{\mathrm{b}^{* *}}$ \\ Gulnur Muradoglu $\mathrm{u}^{\text {**** }}$ \\ Sheeja Sivaprasad $\mathrm{d}^{\mathrm{d} * * * *}$ \\ ${ }^{\mathrm{a}, \mathrm{b}, \mathrm{d}}$ Westminster Business School \\ ${ }^{\mathrm{c}}$ Cass Business School
}

\section{October 2010}

The authors thank Thomas Fullerton Jr, Neville Norman, Ben Nowman, Giorgio Di Pietro, Mafalda Ribeiro, David Shepherd and Peter Urwin for their useful comments and suggestions on this and earlier versions of the paper. The authors thank all participants at the Oxford Business and Economics Conference (OBEC) 2010 and the Westminster Business School Research Conference 2010. The authors are grateful to Sean Holly for the workshop on EViews programming and his further technical expertise and advice. The authors alone are responsible for all limitations and errors that may relate to the paper.

\footnotetext{
* E-mail: r.adami@wmin.ac.uk, Tel: + 44 (0)20 79115000 Ext 3326, Fax: +44(0)20 7911 5839;

**Email:o.gough@wmin.ac.uk, Tel:+ 44 (0)20 79115000 Ext 3012 Fax: +44(0)20 7911 5839;

*** Email: g.muradoglu@ city.ac.uk, Tel+44(0)20 70400124 Fax: +44(0)20 7040 8881;

****Email:sivaprs@wmin.ac.uk, Tel: +44 (0) 44 (0)20 79115000 Ext 3157, Fax: +44(0)20 79115839.
} 


\begin{abstract}
This paper examines the relation between abnormal stock returns and leverage. Expanding on Modigliani and Miller's (1958) Proposition II, abnormal returns are estimated using the asset pricing models of Sharpe and Lintner (the traditional Capital Asset Pricing Model, CAPM), of Fama and French and of Carhart. The findings indicate that returns are decreasing in firm leverage. This paper tests this relation empirically with other risk factors and finds that the results remain robust. The results show that leverage is a firm characteristic that loads on a risk factor. This evidence suggests that leverage should be priced as a risk factor and requires adequate incorporation into common asset pricing models.
\end{abstract}




\section{INTRODUCTION}

This paper investigates the relation between abnormal stock returns and leverage. Accounting literature focuses on the relation between cost of equity and leverage from two perspectives. Penman et al. (2007) show that average returns increase in market leverage but decline in book leverage by decomposing the leverage component of the book-to-market ratio pertaining to financing risk from the component that pertains to operating risk. Dhaliwal et al. (2006) argue that corporate level taxes decrease the effect of leverage on the cost of equity.

This study focuses on the empirical relation between abnormal returns and book leverage pertaining to the financial risk component of leverage. At the firm level cash flows from debt financing are determined by the level of book leverage. The cash flows to the firms from debt financing are best represented by the book leverage. Firms with lower leverage will be perceived as less risky due to lower distress risk and enjoy higher returns. Our results show that indeed abnormal returns decline in book leverage.

We take into account corporate taxes and the competitiveness of the industry where firms operate. Both could have direct effects on returns as well as affecting the relationship between returns and leverage. Corporate taxes provide tax shields and returns might increase due to those tax shields. As the industry become more competitive rates of return decline. Taking taxes into consideration without considering industry structures would be incomplete. Dhaliwal et al. (2006) show that corporate level taxes decrease the effect of market leverage on cost of equity. Their measurement of leverage corresponds to the operating risk component described in Penman et al (2007). We argue that firms paying higher corporate taxes enjoy tax shields which will accentuate the effect of book leverage on stock returns. In 
competitive industries returns will be lower due to pressures from competition. In those industries higher tax rates will further lower the cash flows and returns. However tax shields are still important as sources of additional cash flows. Therefore we would expect corporate taxes to increase the effect of leverage on stock returns in both high and low concentration industries. Our findings show that corporate level taxes increase the effect of leverage.

Many studies in financial literature analyse the decisions on capital structure and leverage. Capital structure decisions are critical as a shift in the firm's attitude to leverage could increase or decrease the financial strains on the company. ModiglianiMiller (1958; henceforth MM) state that the value of a firm is independent of its capital structure (Proposition I), and they argue that as debt increases the riskiness of the stock, equity shareholders will demand a higher return (Proposition II). They test their theorem in a restricted sample consisting of two industries, each representing a risk class, namely the oil sector and the utilities sector and find supporting evidence. The existing empirical evidence, however, appears to show more uncertain results in support of this theory. Some authors (Hamada, 1972; Bhandari, 1988, Dhaliwal et al., 2006) show that returns increase in leverage; other authors show that returns decrease in leverage (Korteweg, 2009, Dimitrov and Jain, 2008, Penman et al., 2007, Muradoglu and Sivaprasad, 2009). The resolution of this issue for the practical conduct of operations in the world's capital market seems important to the current authors. Accordingly this paper explores the link between leverage and stock returns, contributing towards the existing empirical evidence of asset pricing implications of leverage.

Previous empirical work on capital structure is mainly focused on examining the factors that affect capital structure decisions (e.g. Titman and Wessels, 1988; 
Rajan and Zingales, 1995; Booth, Aivazian, Demiguc-Kunt and Maksimovic, 2001; Lally, 2002), and testing the various well-known theories of capital structure (Frank and Goyal, 2003; Flannery and Rangan, 2006, Dang, 2010). Recent studies have attempted to examine the leverage - return relation (Dimitrov and Jain, 2008; Penman et al. 2007; Korteweg, 2009; George and Huang, 2009; Muradoglu and Sivaprasad, 2009). However, these studies use various different representations of returns: accounting profit (Hamada, 1972); inflation adjusted returns (Bhandari, 1988); riskadjusted returns (Korteweg, 2009, Dimitrov and Jain, 2008), market adjusted returns (Muradoglu and Sivaprasad,2009). This paper chooses a robust estimation of returns: the excess return or alpha based on widely used asset pricing models.

The main objective of this paper is to test MM's Proposition II. This paper represent returns to shareholders as abnormal stock returns estimated using the wellrecognised asset pricing models of CAPM, Fama-French (1993) and Fama-French plus Carhart (1997) four factor model that encompasses all the traditional risk factors and is arguably a more robust estimator for returns. This paper measures leverage as the ratio of the book values of total debt to total capital. There is a need to use a broader definition of financial structure in order to account for the large measure of substitutability between the different forms of debt. Using book values encompasses the total of all liabilities and ownership claims (Schwartz, 1959). The use of book values in defining the capital structure ensures that the effects of past financing are best represented (Rajan and Zingales, 1995). Graham and Harvey (2001) report that managers focus on book values when setting financial structures. Additionally, Barclay et al. (2006) show how book leverage is preferable when regressing financial leverage, as using market values in the denominator might spuriously correlate with exogenous variables. This study uses panel data of all non-financial firms listed on the 
London Stock Exchange (LSE) that contains information for twenty-eight years and combines the cross sections with the time series. Besides firm leverage, an analysis of other risk factors at the firm level such as tax rates and industry concentration is also undertaken.

Previous studies have shown the tax effect of debt (Miller, 1977; Martin and Sloane, 1980; Graham, 2000). Their findings suggest that tax rate of a firm is an important determinant of the value of firm. In addition to examining the effect of taxes on stock returns, this paper also conducts the analysis for both tax paying and non-tax paying firms and finds that returns decrease in leverage in both cases, where the tax rate is zero and where it is greater than zero.

Factors influencing different sectors also help explain firms' capital structure. Previous studies have examined the effect of sector on capital structures and stock returns (Mackay and Phillips, 2005) and the degree of concentration (Hou and Robinson, 2006). Hou and Robinson (2006) offer evidence that industry concentration is an important economic determinant for understanding stock returns. Thus this paper also includes industry concentration as an additional variable in the analysis. The results indicate that firms in both low and high concentration sectors have returns that decline in leverage.

The findings indicate emphatically that returns decrease in leverage. This contradicts one of the fundamental principles of traditional finance theory and suggests that there is the need for a better understanding of how leverage is priced. It also indicates that leverage has been largely ignored in common asset pricing models. The negative relation between leverage and returns is also robust to the additional risk factors such tax rates and industry concentration. 
The paper is organised as follows. Section 2 provides the motivation linking firm leverage, taxes, industry concentration and stock returns. Section 3 describes the sample and methods. Section 4 presents the results of the study. Section 5 concludes.

\section{THE LINK BETWEEN LEVERAGE AND STOCK RETURNS}

The seminal work of MM (1958) has led to many studies examining firms' capital structure choices and its relation with other firm characteristics (Harris and Raviv, 1991), Titman and Wessels, 1988, Rajan and Zingales, 1995, Graham and Harvey, 2001) as well as the development of different theories on capital structure including the trade-off theory, the pecking-order theory, agency theory, market timing theory, corporate control theory and product cost theory (Scott,1977; Myers and Majluf,1984; Jensen and Meckling, 1976; Baker and Wurgler, 2002; Agarwal and Mandelker,1987; Campello, 2003). Few studies have examined the effect of capital structure on stock returns (Dimitrov and Jain 2007, George and Hwang, 2009). This paper examines how stock returns of a firm behave in relation to its capital structure. The decision on capital structure is arguably one of the most important decisions managers face, and a change in the leverage ratio can affect a firm's financing capacity, risk, cost of capital, investment and strategic decisions, and ultimately shareholder wealth.

MM (1958) represent equity returns by the average cost of capital in a oneyear period and conduct estimations on a cross-section of a particular risk class. This study represents equity returns as abnormal returns computed from alphas of the three asset pricing models.

According to finance theory, the principal sources of risk are determined by the operating risk and by the financing risk represented by leverage. Penman et al. (2007) decompose the book-to-price ratio into two components; a component that 
pertains to business operations and a component that pertains to financing activities. They observe that the leverage component is negatively associated with stock returns. They argue that this negative relation between leverage and stock returns indicates how leverage should be priced and taken into account whilst evaluating risk in the asset pricing models. The results of this study also indicate a negative relation between stock returns and leverage and suggests that leverage is priced by the market.

MM (1963) explain that due to the tax advantage of debt, it would be beneficial to the shareholders to have debt in the capital structure. The traditional view is that there are tax advantages to debt but that beyond a certain level, these are counter balanced by costs associated with bankruptcy and financial distress. Dhaliwal et al. (2006) examine the relation between leverage, corporate taxes and the firm's implied cost of capital. They find that although the cost of equity capital increases with leverage when corporate taxes are introduced, it reduces the risk premium. Following their work, this paper includes corporate effective tax rates and finds that the returns decrease in leverage where firms' tax rate is zero as well as where it is greater than zero

Schwartz (1959) argues that there exists an optimal capital structure for each firm as long as firms attempt to maximise the long run market value of the shares. This study examines the effect of industry concentration on stock returns as the financing needs of each company could differ according to the sectors they belong to.

Hull (1999) found that the stock value is influenced by how a firm changes its leverage in relationship to its industry leverage. Campello (2003) provides evidence that firms that rely on debt are more likely to reduce their investment in market sharebuilding during downturns. Campello (2003) also shows the effects of capital structure on product market outcomes for a cross section of industries. Arditti (1967) 
explained that some risks are indigenous to each industry grouping and hence the true nature of the leverage return relation can be disclosed only by testing this relation. Baker (1973) investigated the effect of financial leverage on industrial profitability. Hou and Robinson (2006) find that firms in highly concentrated industries earn lower returns. This study undertakes an analysis of the relation between industry concentration and stock returns and finds that the effect of leverage on returns remains negative for low and high concentration firms.

\section{DATA AND METHOD}

The source of all data is Thomson Reuters DataStream. The study starts with the 2,673 companies listed in the London Stock Exchange from 1980 to 2008. To enter the sample, a firm's fiscal year-end leverage ratio and stock price series for at least the preceding 12 months have to be available. All financial companies, including banks, investment companies, insurance and life assurances, and companies that have changed the fiscal period end date during the research period are excluded. Thus, 1,092 financial companies are removed. 490 companies are excluded because they do not have matching year-end leverage ratios and stock prices for all subsequent years. The study also drops 173 companies with short quotation experience. Finally, 130 companies with a market value of less than $£ 1$ million are eliminated. Negative market-to-book values are excluded. The resulting sample contains 10267 firm year-end observations of 792 companies listed on the London Stock Exchange from 1980 onwards.

Firms are ranked according to the leverage that is available from annual reports with year-end dates of December $31^{\text {st }}$ or before, every year. The paper uses the capital gearing definition (DataStream code: WC08221) to represent the 
leverage of companies in the sample. It represents the total debt to total financing of the firm.

The paper also takes into account industry concentration and tax rates as explanatory variables. Tax is the effective corporate tax rate for year $t$. We measure industry concentration using the Herfindahl Index, which is defined as:

$$
\text { Herfindahl }_{j}=\sum_{\mathrm{i}=1}^{\mathrm{I}} \mathrm{s}^{2} \mathrm{ij}
$$

Where $\mathrm{s}_{\mathrm{ij}}$ is the market share of firm $i$ in industry $j$. The study performs the above calculations for each industry and then averages the values over the past three years. This is to ensure that the Herfindahl measure is not unduly influenced by potential data errors (Hou and Robinson, 2006). We use net sales to calculate market share, as this is the most common Herfindahl measure. Small values of the Herfindahl Index $(0-1,800)$ imply that many competing firms operate in the industry, while large values $(1,800-10,000)$ indicate that market share is concentrated in the hands of a few large firms.

Table 1 presents the summary statistics for the four variables: monthly stock returns, leverage, tax-rates and the Herfindahl Index. We calculate leverage, tax and Herfindahl Index as of year-end. The sample's mean and the median returns are -0.02 and -0.05 percent respectively. The distribution is dispersed with a standard deviation of 12.11 percent. The mean and median values for leverage are 27.2 percent and 25.9 percent, respectively, its standard deviation is 19.45 percent, with a range between zero and 99.67 percent. From the JB statistic we observe that there is non-normality in the data set.

[Insert Table 1 here] 


\subsection{Returns Estimation Model}

The paper uses three models that are commonly employed in the literature to estimate abnormal returns for each stock; the capital asset pricing model (CAPM), the Fama-French three factor model and the Fama-French plus Carhart four factor model. Stock returns for each company are calculated monthly, using the percentage change in consecutive closing prices adjusted for dividends, splits and rights issues (Fama et al. 1969). Next, the study estimates abnormal returns in excess of the riskfree rate using Sharpe (1964)'s Capital Asset Pricing Model, Fama-French (1993) model and Carhart (1997) model. For CAPM, the paper estimates the intercept term alpha by performing the regression:

$$
\mathrm{R}_{\mathrm{t}}-\mathrm{r}_{\mathrm{ft}}=\alpha_{\mathrm{CAPM}}+\beta_{1} \text { Exrm }+\varepsilon_{\mathrm{t}}
$$

Re-arranging equation (2), abnormal return is defined as:

$$
\alpha_{\mathrm{CAPM}}=\mathrm{R}_{\mathrm{t}}-\mathrm{r}_{\mathrm{ft}}-\beta_{1} \text { Exrm }
$$

where, $\mathrm{R}_{\mathrm{t}}$ is the monthly stock returns at time $t, \mathrm{r}_{\mathrm{ft}}$ is the one month UK Treasury discount bill used as a proxy for the risk free rate; $\alpha_{\text {CAPM }}$ is the intercept which indicates an abnormal return, $\beta_{1}$ is the slope coefficient from the CAPM regression, Exrm $^{1}$ is the excess return of the market (proxied by the FTSE All Share Index) over the 1 month UK Treasury discount bill and $\varepsilon_{\mathrm{t}}$ is an error term. For the Fama-French three factor model, the paper estimates the intercept as follows:

$$
\mathrm{R}_{\mathrm{t}}-\mathrm{r}_{\mathrm{ft}}=\alpha_{\mathrm{FF}}+\beta_{1} \mathrm{SMB}+\beta_{2} \mathrm{HML}+\beta_{3} \mathrm{Exrm}+\varepsilon_{\mathrm{t}}
$$

Re-arranging equation (4), abnormal return is defined as:

$$
\alpha_{\mathrm{FF}}=\mathrm{R}_{\mathrm{t}}-\mathrm{r}_{\mathrm{ft}}-\beta_{1} \mathrm{SMB}-\beta_{2} \mathrm{HML}-\beta_{3} \text { Exrm }
$$

\footnotetext{
${ }^{1}$ Refer Appendix 2
} 
where, $\mathrm{R}_{\mathrm{t}}$ is the monthly stock returns at time $t, \mathrm{r}_{\mathrm{ft}}$ is the one month UK Treasury discount bill used as a proxy for the risk free rate; $\alpha_{\mathrm{FF}}$ is the intercept which indicates an abnormal return; $\beta_{1}, \beta_{2}, \beta_{3}$ are estimated by regressing stock's monthly excess returns on the monthly market excess returns, market-to-book, and size factor returns for the estimation period. We examine stocks' excess returns based on the portfolio approach formed by sorting companies according to size and market-to-book values. $\mathrm{SMB}^{2}$ is the size mimicking portfolio, $\mathrm{HML}^{3}$ is the market-to-book mimicking portfolio.

Finally, the study determines if abnormal returns can be earned after including a fourth factor, using Carhart's four factor model,

$$
\mathrm{R}_{\mathrm{t}}-\mathrm{r}_{\mathrm{ft}}=\alpha_{\mathrm{FF}+\mathrm{C}}+\beta_{1} \mathrm{SMB}+\beta_{2} \mathrm{HML}+\beta_{3} \mathrm{Exrm}+\beta_{4} \mathrm{MOMENTS}+\varepsilon_{\mathrm{t}}
$$

Re-arranging equation (6), abnormal return is defined as:

$$
\alpha_{\mathrm{FF}+\mathrm{C}}=\mathrm{R}_{\mathrm{t}}-\mathrm{r}_{\mathrm{ft}}-\beta_{1} \mathrm{SMB}-\beta_{2} \mathrm{HML}-\beta_{3} \text { Exrm- } \beta_{4} \text { MOMENTS }
$$

Where $\alpha_{\mathrm{FF}+\mathrm{C}}$ is the intercept which indicates an abnormal return; MOMENTS ${ }^{4}$ is the momentum mimicking portfolio; $\beta_{1}, \beta_{2}, \beta_{3}$ and $\beta_{4}$ are estimated by regressing stock's monthly excess returns on the size factor, market-to-book factor, monthly market excess returns and momentum for the estimation period. In all the above regressions, the intercept term $\alpha$ indicates an abnormal return. To estimate the abnormal returns alpha in the models (3), (5) to (7), for firm $i$ at month $t$ we use 60 monthly excess returns prior to month $t$ for each firm $i$.

\footnotetext{
${ }^{2}$ Refer Appendix 2

${ }^{3}$ Refer Appendix 2

${ }^{4}$ Refer Appendix 2
} 
The next step is to test our hypothesis. We first determine whether abnormal returns at the firm level, as estimated above, can be explained by the leverage of the firms. Following Penman et al (2007) we expect abnormal returns to decline in leverage. Next we examine if corporate level taxes (Dhaliwal et al. 2006) and industry concentration (Hou and Robinson, 2006) have additional explanatory power. Due to tax shield provided by corporate level taxes we expect abnormal returns to increase in taxes. We also expect higher competition in low concentration industries to reduce abnormal returns. We test if the effect of leverage on abnormal returns is increasing in corporate tax rate or decreasing with concentration of the industry by adding an interaction term for each variable. We estimate equations (8) through (10) accordingly. To increase the robustness of our findings we conduct additional estimations for sub-samples of firms with non-zero leverage and zero leverage as well as for firms operating in high and low concentration industries.

$$
\begin{gathered}
\alpha_{\mathrm{it}}=\delta+\lambda \text { Leverage }+\varepsilon_{\mathrm{t}} \\
\alpha_{\mathrm{it}}=\delta+\lambda_{1} \text { Leverage }+\lambda_{2} \text { Herfindahl-Index }+\lambda_{3} \text { Taxrate }+\varepsilon_{\mathrm{t}} \\
\alpha_{\mathrm{it}}=\delta+\lambda_{1} \text { Leverage }+\lambda_{2} \text { Herfindahl-Index }+\lambda_{3} \text { Taxrate }+ \text { Leverage* AvgHI+ } \\
\text { Leverage } * \text { Taxrate }+\varepsilon_{\mathrm{t}}
\end{gathered}
$$

In (8), (9) and (10), $\alpha_{\mathrm{it}}$ are the abnormal returns found for each asset pricing model as in (3), (5) and (7), where $\delta$ stands for constant and leverage is measured as the ratio of total debt to total equity plus debt. Further, in (10) the study examines tax rate which is the effective tax rate paid by companies; the Herfindahl Index and two interaction terms between leverage and industry concentration and leverage and tax rate and $\varepsilon$ is the error term. The paper estimate regressions (8) to (10) using panel 
least square and fixed effects for firms ${ }^{5}$. Following Flannery and Rangan (2006) the paper uses fixed effects for firms in the panel to account for the richness of individual firms' unique information and for the possibility of varying degrees of risk acceptance in ownership decisions (Schwartz, 1959).

\section{FINDINGS}

\subsection{Returns and Leverage}

In this section we present the findings. The paper reports on the relation between firm returns and leverage when monthly rates of return are estimated with the three asset pricing models and undertakes robustness tests. The leverage effect on monthly returns for all three models is negative and significant although very small. It remains negative and significant when we add other risk factors such as tax-rate, and industry concentration. The robustness tests consist of running cross-sectional regressions as in equation (9) for sub-samples of firms. We show that the relation between firm returns and leverage remains significant and negative consistent with Penman et al. (2007).

Table 2 reports the cross-sectional regression results of equations (8) to (10) when excess returns are estimated as in equations (3), (5) and (7) for all firms with leverage ratios ranging from zero to ninety-nine percent. The three columns present the results of the cross-sectional regressions of leverage and stock returns when the returns are estimated using different asset pricing models. The table also reports the results when two other risk factors, tax-rate and industry concentration, are added. For all three models the effect of leverage on return is negative and significant, these findings are also confirmed when tax-rate and industry concentration are added.

\footnotetext{
${ }^{5}$ Alternative estimations were made using OLS and GMM. Conclusions do not change and are hence not reported. Results are available upon request
} 
For the overall sample, when abnormal returns are estimated with the CAPM, as in equation (3), our cross-sectional regressions indicate a negative and significant relation between leverage and returns when leverage is the sole explanatory variable. Returns decline in leverage ${ }^{6}$, for example, the first column shows that a one percent increase in leverage is associated with a 0.04 percent decline in abnormal returns. Next when returns are estimated using the FF model, as in equation (5), our results still indicate a negative and significant relation between leverage and returns when leverage is the sole explanatory variable ${ }^{7}$ However the negative change in return here becomes smaller, as a 1 percent increase in leverage is associated with a 0.01 percent decline in returns.

The results remain similar when we use the four factor Fama-French and Carhart model as in equation (7), we find that a negative and significant relation between leverage and returns ${ }^{8}$ persists, a one percent increase in leverage is associated with a 0.01 percent decline in returns.

Next we report the results of our cross-sectional regressions as per equation(9) when we include tax-rates and industry concentration as additional explanatory variables. Leverage remains negative and significant throughout the analysis. When returns are estimated with the CAPM, we find that firms that are on higher tax rates earn higher returns. In the second column, where returns are estimated using FF, we find that for every one percent increase in leverage, returns fall by 0.01 percent, this is consistent with our previous findings with leverage as the only explanatory variable.

\footnotetext{
${ }^{6}$ Alternative estimations were made using cumulative abnormal returns. Conclusions do not change and are hence not reported. Results are available upon request

${ }^{7}$ Alternative estimations were made using cumulative abnormal returns. Conclusions do not change and are hence not reported. Results are available upon request

${ }^{8}$ Alternative estimations were made using cumulative abnormal returns. Conclusions do not change and are hence not reported. Results are available upon request
} 
The coefficient for the tax rate remains positive as when the study uses CAPM estimates, indicating that firms on higher tax rates achieve higher returns. Finally in the third column, when the study estimates returns using the four-factor model, our findings are confirmed, a negative and significant relation between monthly abnormal returns and leverage persists. For every one percent increase in leverage, the decline in returns remains 0.01 percent. The coefficient for tax rate remains positive although insignificant.

When we add the interaction terms the coefficient estimate for leverage remains negative and significant throughout. The interaction term for leverage and AvgHI tests whether or not the association between leverage and returns is a function of industry concentration holding. When returns are estimated with the CAPM, the coefficient on the interaction term is negative. This shows that high concentration of industry structure reduces the effect of financial leverage on firms. Results remain similar when returns are estimated using the FF model. However when we use the four factor model to estimate returns in the third column the coefficient estimate for the interaction term between leverage and industry concentration becomes positive. The interaction term for leverage and tax rate tests whether the association between leverage and returns is a function of corporate taxes. When returns are estimated with the four factor model, the coefficient on the interaction term is positive. This is evidence that tax benefits arising from higher tax rates increase the effect of leverage on returns. Firms in higher tax brackets enjoy higher tax shields and this increases the negative effect of leverage on returns, as they increase more for high tax firms as leverage declines. This is consistent with Dhaliwal et al (2006) who report that equity risk premium decreases in leverage.

[Insert Table 2 here] 
4.2 Robustness tests on non-zero leverage firms

It is argued (Miller, 1977; Graham, 2000) that there are potential benefits to debt financing; hence as robustness test, here the paper examines the effect of leverage exclusively on non-zero leverage firms. Table 3 presents the cross-sectional regression results when leverage is the sole explanatory variable, as in equation (8) and when other risk factors are added, as per equation (9), on a sample where zero leverage firms are excluded. The paper estimates returns using all three pricing models. When the study uses leverage as sole explanatory variable and estimates returns with the CAPM our results for this sub-sample still indicate a negative and significant relation between leverage and returns. The decline in returns for an additional unit of leverage remains 0.04 percent as it was the case for the overall sample.

The results for this subsample remain unchanged with respect to the overall sample when we estimate abnormal returns with the FF model, as per equation (5). Here again the results indicate a negative and significant relation between leverage and returns but the relation becomes weaker than with the CAPM estimations, a one percent increase in leverage is associated with a 0.01 percent decline in returns. We find that this is also the case when returns are estimated with the FF and Carhart model, a 0.01 percent decline in returns is associated to one percent increase in leverage.

Next, the results for our sub-sample of non-zero leverage firms are reported when tax-rates and industry concentration are included as additional explanatory variables. Leverage remains negative and significant when returns are estimated with 
the CAPM, however its effect on returns declines in strength as a 1 percent increase in leverage now leads to a reduction in returns of 0.005 percent. The coefficient for the tax rate stays positive as it was the case for the overall sample.

When returns are estimated using the FF model and FF plus Carhart the results do not change with respect to the overall sample, the coefficient for leverage remains negative and significant, for a one percent increase in leverage returns fall by 0.01 percent in both models. The results shown in this section indicate that the negative effect of leverage on stock returns remains robust in the subsample of non-zero leverage firms.

When we add the interaction terms the results do not change other than the sign for the interaction between leverage and industry concentration. The coefficient of the interaction term between leverage and industry concentration becomes negative consistent with the findings of Korteweg (2009) that low leverage is a proxy for low distress risk. This suggests that being in a highly concentrated industry reduces the effect of leverage on returns. For firms that are in more competitive, low concentration, industries the negative effect of leverage on returns is larger. Firms in competitive industries enjoy higher risk adjusted returns if they reduce their leverage levels.

[Insert Table 3 here]

\subsection{Tax Effects}

Following Dhaliwal et al. (2006) the paper examines further the relation between leverage and stock returns by dividing the sample into tax-paying and nontax paying firms as we investigate the effect of leverage risk premium in relation to 
tax shields. Table 4 reports the cross-sectional regression results of equations (8), (9) and (10) when returns are estimated using the three pricing models. Firms are classified into two sub-samples, according to whether they pay a tax-rate equal to or greater than zero. The estimates for the leverage coefficients do not change for the two sub-samples of firms for all three models. In the first column where returns are estimated using the CAPM, the coefficient estimate for leverage is negative and significant. A one percent increase in leverage leads to a 0.04 percent decline in returns.

Next, in the second column, when returns are estimated using the FamaFrench model, our results still indicate a negative and significant relation between leverage and returns, however the coefficient here is lower than with the CAPM estimation. A one percent increase in leverage is associated with a 0.01 percent decline in returns. The coefficient for industry concentration is negative only for the sub-sample of non-tax paying firms, while it seems to have no effect on tax-paying firms.

The results are similar when returns estimated using FF and Carhart as reported in the third column. Here again the paper finds a negative and significant relation between leverage and returns. The increase in one percent in leverage remains associated with a 0.01 percent decline in returns.

The results are similar when interaction terms are included. Indeed the interaction between leverage and industry concentration is negative for tax paying firms and positive for non-tax paying firms. This is an interesting result. Firms that do not pay taxes do not enjoy tax shields due to increased leverage. The effect of leverage on returns is accentuated for firms in high concentration industries. The 
effect of leverage on returns is lower for firms that operate in low concentration highly competitive industries.

\section{[Insert Table 4 here]}

\subsection{Industry Concentration}

Following Hou and Robinson (2006), we test the effect of leverage on stock returns by dividing our sample on the basis of the degree of industry concentration. Table 5 reports the cross-sectional regression results when returns are estimated with CAPM, FF and FF plus Carhart and where the firms are classified according to the degree of industry concentration. Firms in industries within a concentration range from $0-1800$ of the HI are classified as low concentration firms while a $\mathrm{HI}$ greater than 1800 denotes firms in high industry concentration. In the first column we report the results for CAPM returns estimates; the results indicate that the coefficient for leverage is negative and significant for firms in highly concentrated industries. The results show that a one percent increase in leverage is associated with a 0.04 percent decline in returns for firms operating in highly concentrated industries. The coefficient estimates for the tax rate remains positive.

Next when returns are estimated with the FF model the results still indicate a negative and significant relation between leverage and returns, however here the effect of leverage appears much smaller than with the CAPM estimates. For example, with a one percent increase in leverage returns fall by 0.01 percent in low concentration industries as well as in high concentration industries. The tax rate coefficient is positive for both sub-samples.

Lastly, returns are estimated with the FF and Carhart model and coefficient results are shown in the last column of Table 5 . We find that a negative and significant relation between leverage and returns persists. Here a one percent increase 
in leverage is associated with a 0.01 percent decline in returns for firms belonging to both low and high concentration industries, while the tax rate coefficient estimate is positive for both sub-samples. The relation remains negative when interaction terms are added. The interaction term for leverage and tax rate remains positive indicating that corporate tax levels increase the effect of leverage on returns.

[Insert Table 5 here]

\section{CONCLUSION}

The objective of this paper is to investigate the effect of firm leverage on stock returns. The paper uses a robust estimation of monthly abnormal returns using three different asset pricing models, namely, Sharpe's Capital Asset Pricing Model (1964), Fama-French (1993) model and Carhart (1997) model. The study defines the intercepts of these regressions as the abnormal returns. In the measure of leverage, the study uses book values for debt and equity, as using book values encompasses the total of all liabilities and ownership claims.

Capital structure theory indicates that the financing risk imposed by leverage should be rewarded with higher returns. In contrast, the results indicate that returns have a negative, albeit small, relation with leverage in all the three models used for the estimation. The results indicate that returns decrease in leverage. The findings are robust to other risk factors and are consistent with Penman et al (2007) who argue that leverage component of Book to Price ratio is negatively associated with future returns. However, the inverse relation between returns and leverage is weaker when returns are estimated with FF and FF plus Carhart than when they are estimated with CAPM. Clearly the risk factors included in these models have additional explanatory power on stock returns. The negative relation of leverage with abnormal returns remains 
unaffected when other factors such as effective tax rates and industry concentration are included in the regression equations. The magnitude of the impact of leverage on abnormal returns diminishes as these variables are taken into consideration, however the relation between leverage and abnormal returns remains significant and negative. 


\section{BIBLIOGRAPHY}

Arditti, F. D. (1967), 'Risk and Return on Equity', Journal of Finance, Vol. 22, No. 1, pp. 19-36.

Agrawal, A., and G. N. Mandelker, (1987), 'Managerial Incentives and Corporate Investment and Financing Decisions', Journal of Finance, Vol. 42, No 4, pp. 823-837.

Baker, S. H. (1973), 'Risk, leverage and profitability: An industry analysis', Review of Economics and Statistics, Vol. 55, No. 4, pp. 503-507.

Baker, M. and J. Wurgler (2002), 'Market Timing and Capital Structure', Journal of Finance, Vol. 57, No. 1, pp. 1-30.

Barclay, M. J., E. Morellec and C. J. Smith (2006), 'On the debt capacity of growth options', Journal of Business, Vol. 79, No.1, pp. 37-58.

Bhandari, L. C. (1988), 'Debt/Equity Ratio and Expected Common Stock Returns: Empirical Evidence', Journal of Finance, Vol.43, No. 2, pp. 507-528.

Booth, L., V. Aivazian, A. Demirguc-Kunt, and V. Maksimovic, (2001), 'Capital Structures in Developing Countries', Journal of Finance, Vol. 56, No. 1, pp. 87130.

Bowen, R., L. Daely and C Huber (1982), 'Evidence on the existence and determinants of Inter-Industry differences in leverage', Financial Management, Winter 82, Vol. 11, No. 4, pp. 10-20.

Bradley, M., G. A. Jarrell and Kim, H. E., (1984), 'On the Existence of an Optimal Capital Structure: Theory and Evidence', Journal of Finance Vol. 39, No. 3, pp. 857-878.

Campello, M., (2003), 'Capital Structure and product markets interactions: Evidence from business cycles', Journal of Financial Economics, Vol. 68, No. 3, pp. 353378.

Carhart, M. M. (1997), 'On Persistence in Mutual Fund Performance', Journal of Finance, Vol. 52, No. 1, pp. 87-82. 
Dang, V. A. , (2010) 'Leverage, Debt Maturity and Firm Investment: An Empirical Analysis', Journal of Business Finance \& Accounting, no. doi: 10.1111/j.14685957.2010.02215.x

Dhaliwal, D. S., S. Heitzman and O. Zhen Li, (2006), 'Taxes, leverage, and the cost of equity capital', Journal of Accounting Research, Vol. 44, No. 4, pp. 691-723.

Dimitrov, V. and P. C. Jain (2008), 'The Value Relevance of Changes in Financial Leverage Beyond Growth in Assets and GAAP Earnings', Journal of Accounting, Auditing and Finance, pp. 191-222.

Fama, E. F., L. Fisher, M.C. Jensen and R.W. Roll, (1969), 'The adjustment of stock prices to new information'. International Economic Review, Vol. 10, No. 1, pp. 121

Fama, E. F., and K. French (1993), 'Common risk factors in the returns on stocks and bonds', Journal of Financial Economics, Vol. 33, No. 1, pp. 3-56.

Flannery, M. J, and K. P. Rangan, (2006), 'Partial Adjustment Towards Target Capital Structures', Journal of Financial Economics, Vol. 79, No. 3, pp. 469-506.

Frank, M. Z. and V. K. Goyal, (2003), 'Testing the Pecking Order Theory of Capital Structure', Journal of Financial Economics, Vol. 67, No. 2, pp. 217-248.

Graham, J. R. (2000), 'How Big Are the Tax Benefits of Debt?' Journal of Finance Vol. 55, No. 5, pp. 1901-1941.

Graham, J. R. and C. R. Harvey (2001), 'The theory and practice of corporate finance: evidence from the field'. Journal of Financial Economics, Vol. 60, No. 2-3, pp. 187-243.

Gordon, M. J. (1959), 'Dividends, Earnings and Stock Prices'. Review of Economics and Statistics, Vol. 41, No. 2, pp. 99-105.

George, T. J. and C. Y. Hwang, (2009), 'A Resolution of the Distress Risk and Leverage Puzzles in the Cross Section of Stock Returns', Journal of Financial Economics, Forthcoming.

Hall, M. and L. Weiss, (1967), 'Firm Size and Profitability'. The Review of Economics and Statistics, Vol. 49, No. 3 pp. 319-331.

Hamada, R. S. (1972), ‘The Effect of the Firm's Capital Structure on the Systematic Risk of Common Stocks'. Journal of Finance Vol. 27, No. 2, pp. 435-452. 
Harris, M. and A. Raviv, (1991). 'The Theory of Capital Structure'. Journal of Finance, Vol. 46, No. 1, pp. 297-355.

Hou, K. and D. T. Robinson, (2006), 'Industry Concentration and Average Stock Returns', Journal of Finance, Vol. 61, No. 4, pp. 1927-1956.

Jensen, M. C. and W. H. Meckling, (1976), 'Theory of the firm, Managerial Behaviour, Agency Costs and Ownership structure'. Journal of Financial Economics, Vol. 3, No. 4, pp. 305-360.

Korteweg, A., (2009), 'The Net Benefits to Leverage', Journal of Finance, Forthcoming.

Lally, M. (2002), 'Time Varying Market Leverage, the Market Risk Premium and the Cost of Capital', Journal of Business Finance \& Accounting, Vol. 29, No. 9-10, pp. 1301-1318

Lintner, J., (1956), 'Distribution of Incomes of Corporations Among Dividends, Retained Earnings and Taxes', The American Economic Review, Vol. 46, No.2, pp. 97-113.

Martin, D. R. and W. R. Sloane, (1980), 'Financial Leverage: A Note on a More Precise Approach', Journal of Business Finance \& Accounting, Vol. 7, No. 4, pp. $585-590$

Masulis, R. W., (1983), 'The Impact of Capital Structure Change on Firm Value: Some Estimates', The Journal of Finance, Vol. 38, No. 1, pp. 107-126.

Mackay, P. and G. M. Phillips, (2005), 'How does Industry Affect Firm Financial Structure?', Review of Financial Studies, Vol. 18, No. 4, pp. 1433-1466.

Miller, M. H., (1977), 'Debt and Taxes', Journal of Finance, Vol. 32, No. 2, pp. 261-275.

Modigliani, F. and M. H. Miller, (1958), 'The cost of capital, corporation finance and the theory of investment'. American Economic Review, Vol. 48, No. 3, pp. 261297.

Modigliani, F. and M. H. Miller, (1963), 'Corporate Income Taxes and the Cost of Capital: A correction', American Economic Review, Vol. 53, No. 3, pp. 433-443.

Muradoglu, G. and S. Sivaprasad, (2009), 'An Empirical Analysis of Capital Structure and Abnormal Returns'. http://ssrn.com/abstract=948393 
Penman, S. H., S. A. Richardson and I. Tuna, (2007), 'The Book-to-Price Effect in Stock Returns: Accounting for Leverage'. Journal of Accounting Research, Vol. 45, No. 2, pp. 427-467.

Rajan, R. and L. Zingales, (1995), 'What do we know about capital structure? Some Evidence from International data', Journal of Finance, Vol. 50, No. 5, pp. 14211460.

Schwartz, E., (1959), 'Theory of the Capital Structure of the Firm', Journal of Finance, Vol. 4, No. 1, pp. 18-39.

Scott, J., (1977), 'Bankruptcy, Secured Debt and Optimal Capital Structure' Journal of Finance, Vol. 32, No. 1, pp. 1-20.

Titman, S. and R. Wessels, (1988), 'The Determinants of Capital Structure Choice'. Journal of Finance, Vol. 43, No. 1, pp. 1-19. 


\section{Table 1 Summary Statistics}

This table reports our cross-sectional regression results on returns, leverage, tax-rate and Herfindahl Index. We have a total of 6852 year-end observations for a sample of 665 companies for the period 1980-2008. We calculate the abnormal returns for the sample of 665 non-financial firms from 19802008. The abnormal returns are estimated by using the asset pricing models of CAPM, Fama-French and Fama-French plus Carhart. To perform the regressions we use panel least square and fixed effects for firms with whitening in the cross-sections. We obtain leverage from Datastream (Datastream code WC08221). Leverage represents the total debt to the total financing of the firms. We rank the leverage of each company from low to high. HI refers to the Herfindahl Index refers to the degree of high concentration of firms. It is estimated by calculating the sum of squared sales based market shares of all firms in that industry in a given year and then averaging over the past three years. Low concentration firms range from 0-1800 and high concentration firms are those that range from 180010000 .

\begin{tabular}{ccccc}
\hline & Stock Returns & Leverage & Tax & Herfindahl Index \\
\hline Mean & -0.02 & 27.15 & 0.27 & 1211.78 \\
Median & -0.05 & 25.86 & 0.30 & 700.70 \\
Std Dev. & 12.11 & 19.45 & 0.14 & 1175.70 \\
Kurtosis & 13.20 & 3.20 & 4.19 & 10.08 \\
Skewness & 0.99 & 0.63 & 1.38 & 2.33 \\
Minimum & -87.76 & 0.00 & 0.00 & 330.53 \\
Maximum & 269.10 & 99.67 & 0.89 & 9741.05 \\
JB stastic & 682378.00 & 531.98 & 603.50 & 30486.20 \\
\hline \hline
\end{tabular}




\section{Table 2 Returns and Leverage}

This table reports our cross-sectional regression results on returns, leverage, tax-rate and Herfindahl Index. We have a total of 6852 year-end observations for a sample of 665 companies for the period 1980-2008. We calculate the abnormal returns for the sample of 665 non-financial firms from 19802008. The abnormal returns are estimated by using the asset pricing models of CAPM, Fama-French and Fama-French plus Carhart. To perform the regressions we use panel least square and fixed effects for firms with whitening in the cross-sections. We obtain leverage from Datastream (Datastream code WC08221). Leverage represents the total debt to the total financing of the firms. We rank the leverage of each company from low to high. HI refers to the Herfindahl Index refers to the degree of high concentration of firms. It is estimated by calculating the sum of squared sales based market shares of all firms in that industry in a given year and then averaging over the past three years. Low concentration firms range from 0-1800 and high concentration firms are those that range from 180010000 .

*** represents significance at $1 \%, * *$ represents significance at $5 \%$ and * represents significance at $10 \%$

\begin{tabular}{|c|c|c|c|}
\hline & CAPM & Fama-French & Fama-French + Carhart \\
\hline C & $1.26^{\star \star \star}$ & $0.42^{* \star \star}$ & $0.52^{* \star *}$ \\
\hline Leverage & $-0.04^{\star \star \star}$ & $-0.01^{\star \star \star}$ & $-0.01^{\star \star \star}$ \\
\hline C & $4.15^{\star \star \star}$ & $0.56^{* * *}$ & $0.75^{\star \star \star}$ \\
\hline Leverage & $-0.04^{* * *}$ & $-0.01^{* * *}$ & $-0.01^{* * *}$ \\
\hline Tax rate & $6.53^{\star \star \star}$ & $0.98^{* * *}$ & $0.70^{\star \star *}$ \\
\hline $\mathrm{HI}$ & 0 & 0 & 0 \\
\hline C & $3.78^{* * *}$ & $0.41^{* * *}$ & $0.76^{* * *}$ \\
\hline Leverage & $-0.03^{\star \star \star}$ & $-0.01^{* * *}$ & $-0.01^{* * *}$ \\
\hline Tax rate & $6.33^{\star \star \star}$ & $0.99^{\star * \star}$ & 0.08 \\
\hline $\mathrm{HI}$ & $-0.01^{* * *}$ & 0 & 0 \\
\hline Leverage ${ }^{\star} \mathrm{AvgHI}$ & $-1.58^{\star \star *}$ & $-0.92^{* \star *}$ & $0.04^{* * *}$ \\
\hline Leverage*Taxrate & 0.01 & -0.09 & $0.02^{* \star *}$ \\
\hline
\end{tabular}




\section{Table 3 Returns and Non-Zero Leverage Firms}

This table reports our cross-sectional regression results on abnormal returns, leverage, tax-rate and Herfindahl Index on a sample of non-zero leverage firms. We have a total of 6852 year-end observations for a sample of 665 companies for the period 1980-2008. We calculate the returns for the sample of 665 non-financial firms from 1980-2008. The abnormal returns are estimated as by using the asset pricing models of CAPM, Fama-French and Fama-French plus Carhart. To perform the regressions we use panel least square and fixed effects for firms with whitening in the cross-sections. We obtain leverage from Datastream (Datastream code WC08221). Leverage represents the total debt to the total financing of the firms. We rank the leverage of each company from low to high. HI is the Herfindahl Index; it refers to the degree of high concentration of firms. It is estimated by calculating the sum of squared sales based market shares of all firms in that industry in a given year and then averaging over the past three years. Low concentration firms range from 0-1800 and high concentration firms are those that range from 1800-10000. *** represents significance at $1 \%$, **represents significance at $5 \%$ and $*$ represents significance at $10 \%$

\begin{tabular}{|c|c|c|c|}
\hline & CAPM & Fama-French & $\begin{array}{l}\text { Fama-French + } \\
\text { Carhart }\end{array}$ \\
\hline C & $1.29^{\star \star *}$ & $0.42^{\star \star \star}$ & $0.50^{\star \star *}$ \\
\hline Leverage & $-0.04^{* * *}$ & $-0.01^{* * *}$ & $-0.01^{* * *}$ \\
\hline C & $4.24^{\star * *}$ & $0.56^{\star \star *}$ & $0.71^{* * *}$ \\
\hline Leverage & $-0.04^{\star \star \star}$ & $-0.01^{\star \star \star *}$ & $-0.01^{\star \star \star *}$ \\
\hline Tax rate & $6.50^{* * *}$ & $0.95^{\star * *}$ & $0.65^{\star \star}$ \\
\hline $\mathrm{HI}$ & 0 & 0 & 0 \\
\hline C & 0.78 & 0.41 & 0.76 \\
\hline Leverage & $-0.03^{\star * *}$ & -0.01 & $-0.01^{* \star *}$ \\
\hline Tax rate & $0.33^{* \star *}$ & 0.9 & 0.08 \\
\hline $\mathrm{HI}$ & 0 & $-0.01^{* \star *}$ & $-0.01^{* \star *}$ \\
\hline Leverage*AvgHI & $-0.15^{\star \star \star}$ & $-0.9^{\star \star *}$ & $-0.01^{* * *}$ \\
\hline Leverage ${ }^{\star}$ Taxrate & 0.01 & 0.01 & $0.02^{* * *}$ \\
\hline
\end{tabular}


Table 4: Returns, Leverage and Tax Effects

This table reports our cross-sectional regression results on abnormal returns, leverage and Herfindahl Index. We have a total of 6852 year-end observations for a sample of 665 companies for the period 1980-2008. We calculate the returns for the sample of 665 non-financial firms from 1980-2008. The abnormal returns are estimated by using the asset pricing models of CAPM, Fama-French and FamaFrench plus Carhart. To perform the regressions we use panel least square and fixed effects for firms with whitening in the cross-sections. We obtain leverage from Datastream (Datastream code WC08221). Leverage represents the total debt to the total financing of the firms. We rank the leverage of each company from low to high. The Herfindahl Index refers to the degree of high concentration of firms. It is estimated by calculating the sum of squared sales based market shares of all firms in that industry in a given year and then averaging over the past three years. Low concentration firms range from 0-1800 and high concentration firms are those that range from 1800-10000.

$* * *$ represents significance at $1 \%, * *$ represents significance at $5 \%$ and $*$ represents significance at $10 \%$

\begin{tabular}{|c|c|c|c|c|c|c|}
\hline & CAPM & & Fama-French & & $\begin{array}{l}\text { Fama-French plus } \\
\text { Carhart }\end{array}$ & \\
\hline & Tax rate $=0$ & Tax rate $>0$ & Tax rate $=0$ & Tax rate $>0$ & Tax rate $=0$ & $\begin{array}{l}\text { Tax } \\
\text { rate }>0\end{array}$ \\
\hline $\mathrm{C}$ & -0.68 & $0.49^{* * \star}$ & $1.56^{* * *}$ & $0.78^{* * *}$ & $2.34^{\star * \star}$ & $0.83^{\star \star *}$ \\
\hline Leverage & $-0.08^{* * *}$ & $-0.01^{* * *}$ & $-0.01^{* * *}$ & $-0.01^{* * *}$ & $-0.01^{* *}$ & $-0.01^{* * *}$ \\
\hline $\mathrm{HI}$ & 0 & 0 & $-0.01^{\star * *}$ & 0 & $-0.01^{* * *}$ & 0 \\
\hline $\mathrm{C}$ & 11.06 & 4.73 & 1.86 & 0.64 & 1.94 & 0.7 \\
\hline Leverage & $-0.07^{* * *}$ & -0.01 & $-0.01^{* * *}$ & -0.01 & $-0.01^{* * *}$ & 0 \\
\hline $\mathrm{HI}$ & $-0.01^{\star * *}$ & $-0.02^{* * *}$ & $-0.01^{* * *}$ & $0^{* * *}$ & 0 & $0^{\star \star \star *}$ \\
\hline Leverage*AvgHI & $0.1^{\star \star \star}$ & $-0.5^{\star \star \star}$ & $0.2^{\star \star \star}$ & $-0.01^{\star \star *}$ & 0.44 & $0^{\star \star \star}$ \\
\hline
\end{tabular}




\section{Table 5: Returns, Leverage and Industry Concentration}

This table reports our cross-sectional regression results on abnormal returns, leverage, tax-rate and Herfindahl Index. We have a total of 6852 year-end observations for a sample of 665 companies for the period 1980-2008. We calculate the returns for the sample of 665 non-financial firms from 1980-2008. The abnormal returns are estimated by using the asset pricing models of CAPM, Fama-French and Fama-French plus Carhart. To perform the regressions we use panel least squares and fixed effects for firms with whitening in the cross-sections. We obtain leverage from Datastream (Datastream code WC08221). Leverage represents the total debt to the total financing of the firms. We rank the leverage of each company from low to high. The Herfindahl Index refers to the degree of high concentration of firms. It is estimated by calculating the sum of squared sales based market shares of all firms in that industry in a given year and then averaging over the past three years. Low concentration firms range from 0-1800 and high concentration firms are those that range from 1800-10000.

$* * *$ represents significance at $1 \%, * *$ represents significance at $5 \%$ and $*$ represents significance at $10 \%$

\begin{tabular}{|c|c|c|c|c|c|c|}
\hline & CAPM & & Fama-French & & $\begin{array}{l}\text { Fama-French } \\
\text { plus Carhart }\end{array}$ & \\
\hline & $\mathrm{HI}<1800$ & $\mathrm{HI}>1800$ & $\mathrm{HI}<1800$ & $\mathrm{HI}>1800$ & $\mathrm{HI}<1800$ & $\mathrm{HI}>1800$ \\
\hline C & $-1.38^{\star * *}$ & $-2.40^{\star * *}$ & $1.86^{\star * *}$ & $-1.04^{* \star *}$ & $2.11^{\star \star \star}$ & $-0.76 * * *$ \\
\hline Leverage & 0 & $-0.04^{\star \star *}$ & $-0.01^{\star \star \star}$ & $-0.01^{* * *}$ & $-0.01^{* * *}$ & $-0.01 * * *$ \\
\hline Tax rate & $9.52^{* * *}$ & $4.25^{\star \star \star}$ & $1.05^{\star \star \star}$ & $0.87^{\star * *}$ & $0.86^{* * *}$ & $0.42 * * *$ \\
\hline $\mathrm{HI}$ & 0 & 0 & 0 & 0 & 0 & 0 \\
\hline C & 7.92 & 7.38 & 1.76 & -1.38 & 2.02 & -0.59 \\
\hline Leverage & $-0.04^{\star * *}$ & $-0.1^{* * *}$ & $-0.01^{* * *}$ & 0 & $-0.01^{* * *}$ & $-0.01^{* * *}$ \\
\hline Tax rate & $6.36^{\star \star \star}$ & $7.64^{\star * *}$ & $1.2^{* * *}$ & $1.06^{\star \star *}$ & $0.66^{* * *}$ & $-1.04^{* * *}$ \\
\hline $\mathrm{HI}$ & $-0.01^{* * *}$ & 0 & 0 & 0 & 0 & 0 \\
\hline Leverage ${ }^{\star} \mathrm{Avg} \mathrm{HI}$ & 0 & 0 & 0 & 0 & 0 & 0 \\
\hline Leverage*Taxrate & 0 & 0 & $-0.01^{*}$ & 0 & $0.01^{*}$ & $0.04^{* * *}$ \\
\hline
\end{tabular}


Appendix 1 UK SIC Industry Classification

\begin{tabular}{|c|c|c|}
\hline Code & Industry & Sector \\
\hline 1 & Oil and gas & $\begin{array}{l}\text { Oil \& Gas Producers } \\
\text { Oil Equipment \& Services }\end{array}$ \\
\hline 1000 & Basic Materials & $\begin{array}{l}\text { Chemicals } \\
\text { Forestry \& Paper } \\
\text { Industrial Metals } \\
\text { Mining }\end{array}$ \\
\hline 2000 & Industrials & $\begin{array}{l}\text { Construction \& Materials } \\
\text { Aerospace \& Defense } \\
\text { General Industries } \\
\text { Electronic \& Electric Equipment } \\
\text { Industrial Engineering } \\
\text { Industrial Transportation } \\
\text { Support Services }\end{array}$ \\
\hline 3000 & Consumer Goods & $\begin{array}{l}\text { Automobiles \& Parts } \\
\text { Beverages } \\
\text { Food Producers } \\
\text { Household Goods } \\
\text { Leisure Goods } \\
\text { Personal Goods }\end{array}$ \\
\hline 4000 & Healthcare & $\begin{array}{l}\text { Healthcare Equipment \& Services } \\
\text { Pharmaceuticals \& Biotechnology }\end{array}$ \\
\hline 5000 & Consumer Services & $\begin{array}{l}\text { Food \& Drug Retailers } \\
\text { General Retailers } \\
\text { Media } \\
\text { Travel \& Leisure }\end{array}$ \\
\hline 6000 & Telecommunications & $\begin{array}{l}\text { Fixed Line Telecommunications } \\
\text { Mobile Telecommunications }\end{array}$ \\
\hline 7000 & Utilities & $\begin{array}{l}\text { Electricity } \\
\text { Gas, Water \& Multi utilities }\end{array}$ \\
\hline 9000 & Technology & $\begin{array}{l}\text { Software \& Computer Services } \\
\text { Technology } \quad \text { Hardware } \quad \text { \& } \\
\text { Equipment }\end{array}$ \\
\hline
\end{tabular}




\section{Appendix 2}

a) Size Factor (SMB)

The portfolio SMB (small minus big) is meant to mimic the risk factor in returns related to size (FF 1993). It is the difference, each month between the simple average of the returns on the three small stock portfolios $(\mathrm{S} / \mathrm{L}, \mathrm{S} / \mathrm{M}$, and $\mathrm{S} / \mathrm{H})$ and the simple average of the returns on the three big-stock portfolios $(\mathrm{B} / \mathrm{L}, \mathrm{B} / \mathrm{M}$ and $\mathrm{B} / \mathrm{H})$ Hence, SMB is the difference between the returns of the small and big stock portfolios.

b) Market-to-Book Factor (HML)

The portfolio HML (high minus low) is meant to mimic the risk factor in returns related to market-to-book equity (FF 1993). It is the difference each month between the simple average of the returns on the two high-ME/BE portfolios $(\mathrm{S} / \mathrm{H}$ and $\mathrm{B} / \mathrm{H})$ and the average of the returns on the two low ME/BE portfolios ( $\mathrm{S} / \mathrm{L}$ and $\mathrm{B} / \mathrm{L}$ ). Thus, HML is the difference between the returns of the high ME/BE and low ME/BE stock portfolios.

c) Momentum Factor (MOMENTS)

The portfolio MOMENTS (high minus low) meant to mimic the risk factor in returns related to momentum (Carhart 1997). It is the difference each month between the simple average of the returns on the three (deciles $8,9,10)$ high returns portfolios and the average of the returns on the three(deciles 1,2,3) low returns portfolios. Thus, MOMENTS is the difference between the returns of the high and low returns stock portfolios. 
d) Market Risk Factor (Exrm)

Finally, following FF (1993), Exrm is the proxy for the market factor in stock returns which is the excess market return over the one month UK treasury discount bill. 